Editors' Note: In WriteClick this week, Drs. Lynch and Houlden point out an error in the Mystery Case Responses section of "Mystery Case: CSF-1R mutation is a cause of intracranial cerebral calcifications, cysts, and leukoencephalopathy," in which CSF-1R-related leukoencephalopathy is mistaken to be the same as Labrune syndrome. Drs. Lynch and Houlden and author Ayrignac discuss the differences between the 2 disorders. A correction appears on page 1979.

-Megan Alcauskas, MD, and Robert C. Griggs, MD

LETTER RE: MYSTERY CASE: CSF-1R MUTATION IS A CAUSE OF INTRACRANIAL CEREBRAL CALCIFICATIONS, CYSTS, AND LEUKOENCEPHALOPATHY

David S. Lynch, Henry Houlden, London: Ayrignac et al. ${ }^{1}$ presented an interesting case that highlighted the importance of CSF-1R in adult-onset leukoencephalopathies. However, we are concerned that the discussion by Dr. Ganesh in the Mystery Case Responses section confused 2 different diseases as the same. ${ }^{1}$ This case clearly described a typical presentation of CSF-1R-related disease with apparent autosomal dominant inheritance. However, Dr. Ganesh described this as a case of Labrune syndrome (leukoencephalopathy with calcifications and cysts), an autosomal recessive disorder caused by mutations in SNORD $118 .^{2}$ While calcifications occur in both syndromes, they are far more widespread and severe in Labrune syndrome and the imaging appearance of both conditions is distinctive. Dr. Ganesh incorrectly attributed $11 \%$ of adult-onset leukoencephalopathy to Labrune syndrome by referencing Guerreiro et al., ${ }^{3}$ who clearly referred to CSF-1R-related disease.

In our experience of adult-onset leukoencephalopathy, the most common causes are classic leukodystrophies, CSF-1R, CADASIL, and AARS2 mutations. Therefore, it is not surprising that so few residents chose Labrune syndrome or Coats-plus syndrome as likely diagnoses.

1. Ayrignac X, Mouzat K, Magnin E, et al. Mystery Case: CSF-1R mutation is a cause of intracranial cerebral calcifications, cysts, and leukoencephalopathy. Neurology 2016; 87:e262-e263.
2. Jenkinson EM, Rodero MP, Kasher PR, et al. Mutations in SNORD118 cause the cerebral microangiopathy leukoencephalopathy with calcifications and cysts. Nat Genet 2016; 48:1185-1192.

3. Guerreiro R, Kara E, Le Ber I, et al. Genetic analysis of inherited leukodystrophies: genotype-phenotype correlations in the CSF1R gene. JAMA Neurol 2013;70:875-882.

(C) 2017 American Academy of Neurology

\section{AUTHOR RESPONSE: MYSTERY CASE: CSF-1R MUTATION IS A CAUSE OF INTRACRANIAL CEREBRAL CALCIFICATIONS, CYSTS, AND LEUKOENCEPHALOPATHY}

Xavier Ayrignac, Montpellier, France: I thank Dr. Lynch and Prof. Houlden for the important comment on our Mystery Case. ${ }^{1}$ Indeed, calcifications and cysts found in patients with SNORD118 mutations, formerly described in Labrune syndrome, are larger than those seen in patients harboring CSF-1R mutations. Nevertheless, the importance of calcifications in this disorder was recently emphasized. ${ }^{2}$ Notably, calcifications are small and may have a particular steppingstone appearance in the frontal pericallosal regions. ${ }^{2}$

I agree that Labrune syndrome is rare. In our series of 154 patients with adult-onset leukoencephalopathies, only one patient had a radiologic phenotype consistent with Labrune syndrome. ${ }^{3}$ The one other patient identified with leukoencephalopathy with calcifications and cysts was ultimately found to have a mutation in the CSF-1R gene.

1. Ayrignac X, Mouzat K, Magnin E, et al. Mystery Case: $C S F-1 R$ mutation is a cause of intracranial cerebral calcifications, cysts, and leukoencephalopathy. Neurology 2016;87:e262-e263.

2. Konno T, Broderick DF, Mezaki N, et al. Diagnostic value of brain calcifications in adult-onset leukoencephalopathy with axonal spheroids and pigmented glia. AJNR Am J Neuroradiol 2017;38:77-83

3. Ayrignac X, Carra-Dalliere C, Menjot de Champfleur N, et al. Adult-onset genetic leukoencephalopathies: a MRI pattern-based approach in a comprehensive study of 154 patients. Brain 2015;138:284-292.

(C) 2017 American Academy of Neurology

SUMMARY AUTHOR RESPONSE: MYSTERY CASE: CSF-1R MUTATION IS A CAUSE OF INTRACRANIAL CEREBRAL CALCIFICATIONS, CYSTS, AND LEUKOENCEPHALOPATHY

Aravind Ganesh, Oxford, UK: I thank Dr. Lynch and Prof. Houlden for the response to my editorial 
summary accompaniment to the Mystery Case, ${ }^{1}$ and for highlighting the distinction between CSF-1Rrelated disease and Labrune syndrome for both myself and our readers. This is a helpful learning point I hope to carry forward.
1. Ayrignac X, Mouzat K, Magnin E, et al. Mystery Case: CSF-1R mutation is a cause of intracranial cerebral calcifications, cysts, and leukoencephalopathy. Neurology 2016; $87: \mathrm{e} 262-\mathrm{e} 263$

(C) 2017 American Academy of Neurology

\section{CORRECTION}

Mystery Case: $C S F-1 R$ mutation is a cause of intracranial cerebral calcifications, cysts, and

leukoencephalopathy

In the Mystery Case "CSF-1R mutation is a cause of intracranial cerebral calcifications, cysts, and leukoencephalopathy" by X. Ayrignac et al.," there are errors related to the description of diseases within the "Mystery Case Responses." The case described a typical presentation of $C S F-1 R$-related disease rather than a case of Labrune syndrome and should have been written as such. In addition, $11 \%$ of adult-onset leukoencephalopathy should have been attributed to CSF-1R-related disease rather than Labrune syndrome. ${ }^{2}$ The "Mystery Case Responses" author regrets the errors.

\section{REFERENCES}

1. Ayrignac X, Mouzat K, Magnin E, et al. Mystery Case: CSF-1R mutation is a cause of intracranial cerebral calcifications, cysts, and leukoencephalopathy. Neurology 2016;87:e262-e263.

2. Guerreiro R, Kara E, Le Ber I, et al. Genetic analysis of inherited leukodystrophies: genotype-phenotype correlations in the CSF1R gene. JAMA Neurol 2013;70:875-882. 


\title{
Neurology
}

\author{
Summary author response: Mystery Case: $C S F-1 R$ mutation is a cause of intracranial \\ cerebral calcifications, cysts, and leukoencephalopathy \\ Aravind Ganesh \\ Neurology 2017;88;1978-1979 \\ DOI 10.1212/WNL.0000000000003950
}

\section{This information is current as of May 15, 2017}

Updated Information \& Services

References

Permissions \& Licensing

Reprints including high resolution figures, can be found at: http://www.neurology.org/content/88/20/1978.4.full.html

This article cites 1 articles, 1 of which you can access for free at: http://www.neurology.org/content/88/20/1978.4.full.html\#\#ref-list-1

Information about reproducing this article in parts (figures,tables) or in its entirety can be found online at:

http://www.neurology.org/misc/about.xhtml\#permissions

Information about ordering reprints can be found online: http://www.neurology.org/misc/addir.xhtml\#reprintsus

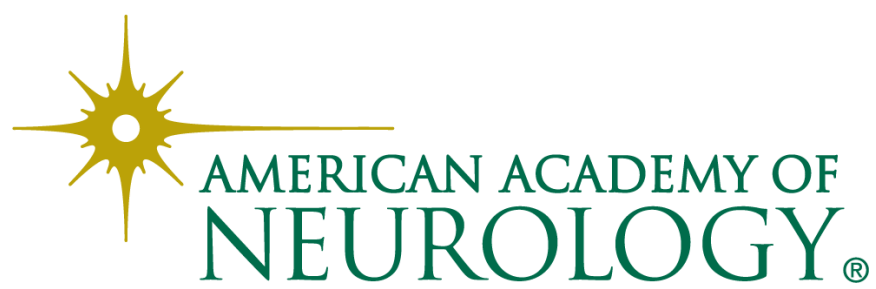

